\title{
Effect of Seed Storage and Seed Treatments on Seedling Growth of Garcinia gummi-gutta (L.) Roxb. in Ponnampet, Western Ghat
}

\author{
Aditya Kumar Jayant ${ }^{1}$, N.M. Poonacha ${ }^{1}$, G.M. Devagiri ${ }^{1}$, \\ Vijay Kumar Yadav ${ }^{2 *}$ and P.S. Chauhan ${ }^{3}$
}

${ }^{1}$ College of Forestry Ponnampet, University of Agricultural and Horticultural Sciences, Shivamogga, Karnataka 577204, India

${ }^{2}$ Department of Forestry and Natural Resources, HNB Garhwal University, SrinagarGarhwal, Uttarakhand 246174, India

${ }^{3}$ College of Horticulture and Forestry, Jhalrapatan, Jhalawar, Agriculture University, Kota-326 023, India

*Corresponding author

\section{A B S T R A C T}

K e y w or d s
$\begin{aligned} & \text { Garcinia gummi-gutta, } \\ & \text { Growth, Seedling, } \\ & \text { Seed storage, Seed } \\ & \text { treatment }\end{aligned}$
Article Info
$\begin{aligned} & \text { Accepted: } \\ & \text { 30 April } 2018 \\ & \text { Available Online: } \\ & \text { 10 June } 2018\end{aligned}$

\section{Introduction}

Genus Garcinia belongs to the family Clusiaceae (Guttiferrae). It is composed of approximately 400-600 species, including dioecious evergreen trees growing in the tropical parts of the world (Steentolft, 1988; Richards, 1990). Garcinia gummi-gutta (L.) Roxb. is a moderate sized tree with round canopy, drooping branches (Shringeshwara et al., 2000) and the trees have a dark, smooth bark with an average thickness of $5.3 \mathrm{~mm}$ (Hegde et al., 1998). These trees grow up to an average height of $18 \mathrm{~m}$ and attain diameter of up to $70 \mathrm{~cm}$. Gacinia gummi-gutta trees are dioecious, with a male to female sex ratio of $1: 1$. Trees of both the sexes usually commence flower production when they are about $14 \mathrm{~cm}$ in diameter. Male and female trees produce flowers from early February to April. Fruits ripen from June to August. Fruit is an indehiscent berry, pulp juicy and weigh about 
$80 \mathrm{~g}$ (Saldanha, 1984). The English name of the tree is Malabar Gamboge. In Kannada it is known as Simai Hunase, and Uppage (Saldanha, 1984). The scientific name of the species is derived from a botanist Garcinia who described it in 1547 (Subhas, 1996). Garcinia gummi-gutta is also known as Garcinia cambogia, probably got its name from the gum tree gummi-gutta or gamboges used as pigment in miniature paintings and water colors (Bhandari, 1998).

Garcinia gummi-gutta, is a common medicinal plant, has been used historically to treat respiratory infections such as sore throat and cough. The phyto-chemical constituents include bi-flavinoid, xanthone and benzophenones and principle acid in the fruit and rind is Hydroxycitric Acid (HCA) (Jayaprakash and Sakariah, 1998). The acid has been found to suppress fatty acid synthesis, lipogenesis, and food intake and to promote glycogenesis, while inducing weight loss (Jena et al., 2002). The sun dried rind of the fruit is astringent, antiseptic and purgative. Due to its commercial importance several farmers of the Western Ghats have shown interest in bringing the species under cultivation (Vasudeva et al., 2003).

Owing to these important properties the demand for the fruit has increased, which in turn has led to the unscientific and reckless exploitation. In rural areas of the Western Ghats, people harvest the fruits even when they are green and there are also instances of severe loping of branches for easy collection of fruits. As a result, the species has already been declared as "threatened" as per the IUCN guidelines (Ravi Kumar and Ved, 2000; Ramesh et al., 1997).

\section{Materials and Methods}

The present study was conducted at college of forestry, Ponnampet, Kodagu district, Karnataka. Fruits were collected from healthy and high yielding mother plants from nearby estates in Ponnampet, Kodagu during month of July. Seeds were extracted from the fruit of Garinia gummi-gutta and wash thoroughly to remove pulp. The experiment was conducted in split plot design with four replications in that seed storage selected as main plot and seed treatment as sub plot. In the present study seed stored up to $0,30,60,90$ days respectively with the eight different seed treatments. In each treatment 30 seeds were used per replication. Observation on growth recorded after 180 day of sowing for each storage period. The data collected was subjected to analysis of variance (adjusted for covariate) based on Split plot design using the GENSTAT software (Genstat 5 Release 3.2) after angular transformation of per cent values and square root transformation of count. The covariates considered for the analysis of covariance is Air temperature.

\section{Treatment details}

Main plot- storage

$\mathrm{M}_{1}$ : Sowing of fresh seeds.

$\mathrm{M}_{2}$ : Sowing after 30 days storage.

$\mathrm{M}_{3}$ : Sowing after 60 days storage.

$\mathrm{M}_{4}$ : Sowing after 90 days storage.

Sub plot - Seed treatments

$\mathrm{S}_{1} \quad$ Control (soaking in water)

$\mathrm{S}_{2} \quad$ Mechanical damaging of seed coat

$\mathrm{S}_{3} \quad$ Acid scarification for 3 minute

$\mathrm{S}_{4} \quad$ Treatment of kernel with 50 ppm $\mathrm{GA}_{3}$ after removal of seed coat

$\mathrm{S}_{5} \quad$ Cow dung slurry treatment for 48 hours

$\mathrm{S}_{6} \quad$ Hot water treatment for 30 minutes

$\mathrm{S}_{7} \quad \mathrm{H}_{2} \mathrm{O}_{2}(30 \%)$ treatment for 30 minutes

$\mathrm{S}_{8} \quad$ Fresh cow urine treatment for 24 hour

\section{Observations recorded}

Root and shoot length $(\mathrm{cm})$ : Root and shoot length of seedlings was taken by the help of scale after 180 days of sowing, the seedlings 
were carefully uprooted with least disturbance to the root from the soil. Root portion was washed to remove the soil. Shoot length was measured from collar region to the top most nodal region. The root length was measured from collar region to the tip of the longest root. For each treatment one seedling was taken.

Collar diameter $(\mathrm{cm})$ : Collar diameter of seedling was taken by using digital calliper.

Average Number of leaves: Leaves were counted after 180 days of sowing.

Root and shoot biomass (g/plant): Dry weight of root and shoot were taken by harvesting one plant from each of the replication for storage and seed treatment by keeping in hot air oven at $70^{\circ} \mathrm{C}$ for 72 hours.

\section{Results and Discussion}

\section{Effect of storage on seedling growth}

The study revealed that the effect of seed storage on seed germination showed significant differences for growth parameters except root length. Out of the different storage period tried, seed stored up to 60 days after collection recorded the higher collar diameter, average number of leaves, root length and shoot length while the shoot weight and root weight were found maximum in seed stored up to 90 days after collection of seed. The minimum growth parameter were observed in fresh seeds except collar diameter which is found minimum in seed stored up to 90 days (Table 1).

Table.1 Effect of seed storage on seedling growth parameters

\begin{tabular}{|c|c|c|c|c|c|c|}
\hline Storage & $\begin{array}{c}\text { Collar } \\
\text { diameter } \\
(\mathbf{m m})\end{array}$ & $\begin{array}{c}\text { Average } \\
\text { number of } \\
\text { leaves per } \\
\text { plant }\end{array}$ & $\begin{array}{c}\text { Root } \\
\text { length } \\
(\mathbf{c m})\end{array}$ & $\begin{array}{c}\text { Shoot } \\
\text { length }(\mathbf{c m})\end{array}$ & $\begin{array}{c}\text { Root } \\
\text { weight } \\
(\mathbf{g})\end{array}$ & $\begin{array}{c}\text { Shoot } \\
\text { weight } \\
(\mathbf{g})\end{array}$ \\
\hline $\mathbf{M}_{\mathbf{1}}$ & $2.06^{\mathrm{b}}$ & $\begin{array}{c}8.80^{\mathrm{a}} \\
(2.9)^{*}\end{array}$ & 13.92 & $11.67^{\mathrm{a}}$ & $0.61^{\mathrm{a}}$ & $0.93^{\mathrm{a}}$ \\
\hline $\mathbf{M}_{\mathbf{2}}$ & $2.21^{\mathrm{c}}$ & $\begin{array}{c}10.73^{\mathrm{b}} \\
(3.28)\end{array}$ & 15.15 & $12.60^{\mathrm{b}}$ & $0.71^{\mathrm{b}}$ & $1.06^{\mathrm{ab}}$ \\
\hline $\mathbf{M}_{3}$ & $2.25^{\mathrm{c}}$ & $\begin{array}{c}11.92^{\mathrm{c}} \\
(3.45)\end{array}$ & 15.71 & $13.44^{\mathrm{b}}$ & $0.75^{\mathrm{c}}$ & $1.12^{\mathrm{b}}$ \\
\hline $\mathbf{M}_{\mathbf{4}}$ & $1.84^{\mathrm{a}}$ & $\begin{array}{c}9.01^{\mathrm{a}} \\
(3.01)\end{array}$ & 14.69 & $12.71^{\mathrm{b}}$ & $1.15^{\mathrm{d}}$ & $1.53^{\mathrm{c}}$ \\
\hline $\mathbf{M e a n}$ & 2.09 & $\begin{array}{c}10.08 \\
(3.18)\end{array}$ & 14.86 & 12.60 & 0.80 & 0.60 \\
\hline $\mathbf{S E m} \pm$ & 0.04 & 0.09 & 0.47 & 0.27 & 0.03 & 0.13 \\
\hline $\mathbf{L S D}(\mathbf{0 . 0 5})$ & 0.15 & 0.30 & $\mathrm{NS}$ & 0.92 & 0.09 & 0.17 \\
\hline
\end{tabular}

*Values in Parentheses are square root transformed; LSD- Least Significant Difference NSNon Significant, Figure with similar letters as superscript do not differ significantly 
Table.2 Effect of seed treatments on seedling growth parameters

\begin{tabular}{|c|c|c|c|c|c|c|}
\hline Treatments & $\begin{array}{c}\text { Collar } \\
\text { diameter } \\
(\mathbf{m m})\end{array}$ & $\begin{array}{c}\text { Average number } \\
\text { of leaves per } \\
\text { plant }\end{array}$ & $\begin{array}{c}\text { Root } \\
\text { length } \\
\mathbf{( c m})\end{array}$ & $\begin{array}{c}\text { Shoot } \\
\text { length } \\
(\mathbf{c m})\end{array}$ & $\begin{array}{c}\text { Root } \\
\text { weight } \\
(\mathbf{g})\end{array}$ & $\begin{array}{c}\text { Shoot } \\
\text { weight } \\
(\mathbf{g})\end{array}$ \\
\hline $\mathbf{S}_{\mathbf{1}}$ & $2.38^{\mathrm{c}}$ & $12.55^{\mathrm{d}}(3.54)^{*}$ & $16.62^{\mathrm{b}}$ & $13.21^{\mathrm{c}}$ & $0.74^{\mathrm{c}}$ & $1.34^{\mathrm{b}}$ \\
\hline $\mathbf{S}_{\mathbf{2}}$ & $2.63^{\mathrm{c}}$ & $13.68^{\mathrm{e}}(3.70)$ & $17.37^{\mathrm{bc}}$ & $15.58^{\mathrm{d}}$ & $1.23^{\mathrm{e}}$ & $1.77^{\mathrm{c}}$ \\
\hline $\mathbf{S}_{\mathbf{3}}$ & $1.66^{\mathrm{b}}$ & $8.68^{\mathrm{b}}(2.95)$ & $10.25^{\mathrm{a}}$ & $10.71^{\mathrm{b}}$ & $0.57^{\mathrm{bc}}$ & $0.59^{\mathrm{a}}$ \\
\hline $\mathbf{S}_{\mathbf{4}}$ & $2.53^{\mathrm{c}}$ & $12.04^{\mathrm{c}}(3.47)$ & $19.33^{\mathrm{c}}$ & $17.37^{\mathrm{d}}$ & $1.22^{\mathrm{e}}$ & $1.70^{\mathrm{c}}$ \\
\hline $\mathbf{S}_{\mathbf{5}}$ & $2.41^{\mathrm{c}}$ & $12.22^{\mathrm{c}}(3.50)$ & $18.62^{\mathrm{bc}}$ & $13.63^{\mathrm{c}}$ & $0.93^{\mathrm{d}}$ & $1.53^{\mathrm{bc}}$ \\
\hline $\mathbf{S}_{\mathbf{6}}$ & $1.29^{\mathrm{a}}$ & $5.16^{\mathrm{a}}(2.27)$ & $8.92^{\mathrm{a}}$ & $8.54^{\mathrm{a}}$ & $0.40^{\mathrm{ab}}$ & $0.40^{\mathrm{a}}$ \\
\hline $\mathbf{S}_{\mathbf{7}}$ & $1.42^{\mathrm{ab}}$ & $4.89^{\mathrm{a}}(2.21)$ & $10.58^{\mathrm{a}}$ & $8.46^{\mathrm{a}}$ & $0.36^{\mathrm{a}}$ & $0.31^{\mathrm{a}}$ \\
\hline $\mathbf{S}_{\mathbf{8}}$ & $2.40^{\mathrm{c}}$ & $12.17^{\mathrm{c}}(3.49)$ & $17.21^{\mathrm{b}}$ & $13.33^{\mathrm{c}}$ & $0.97^{\mathrm{d}}$ & $1.60^{\mathrm{bc}}$ \\
\hline $\mathbf{M e a n}_{\mathbf{S} \mathbf{S} \mathbf{m} \pm}$ & 2.09 & $10.8(2.19)$ & 14.86 & 12.60 & 0.80 & 1.16 \\
\hline $\mathbf{L S D}(\mathbf{0 . 0 5})$ & 0.10 & 0.10 & 0.73 & 0.65 & 0.06 & 0.12 \\
\hline
\end{tabular}

*Values in Parentheses are square root transformed; LSD- Least Significant Difference, Figure with similar letters as superscript do not differ significantly

Fig.1 Effect of different treatments on germination per cent

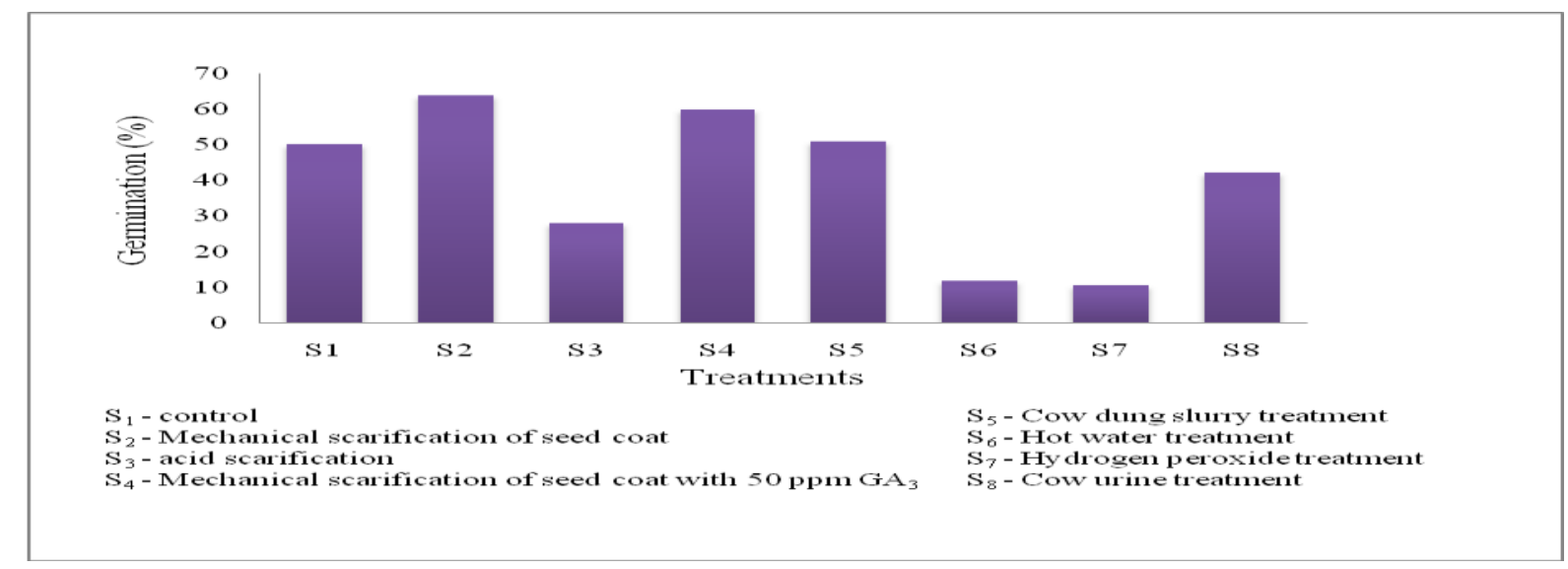

Plate.1 Influence of seed treatments on seedling growth in fresh seeds

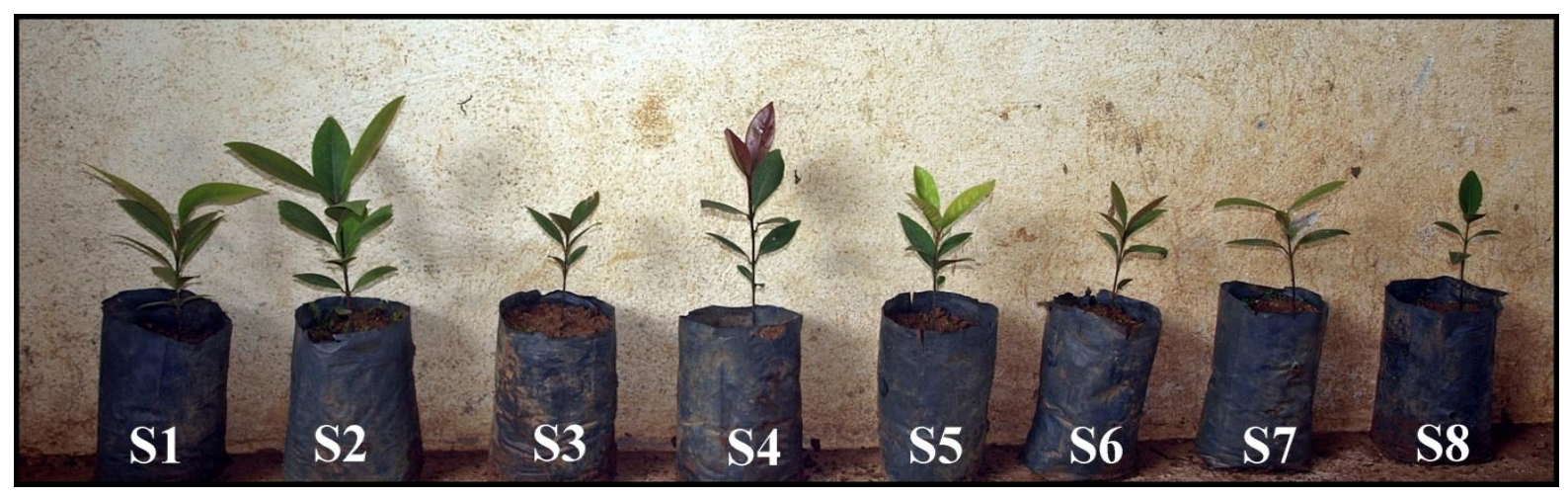


Plate 2: Influence of seed treatments on seedling growth in seed stored for 30 days

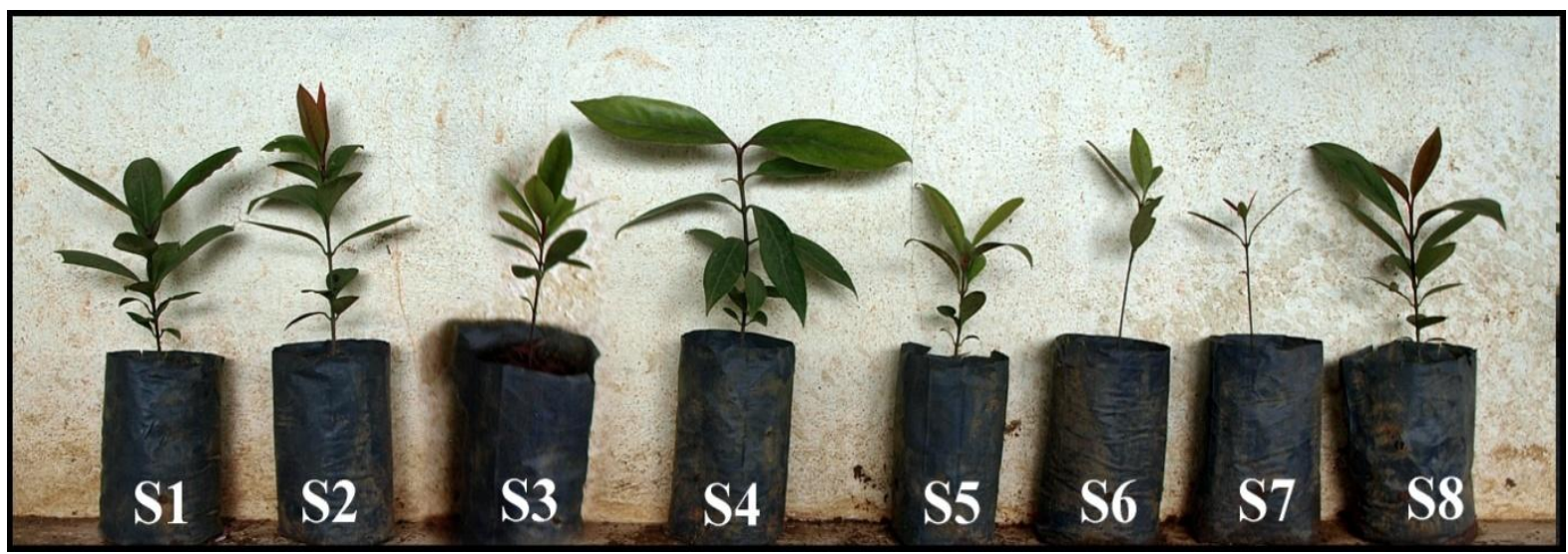

Plate 3: Influence of seed treatments on seedling growth in seed stored for 60 days

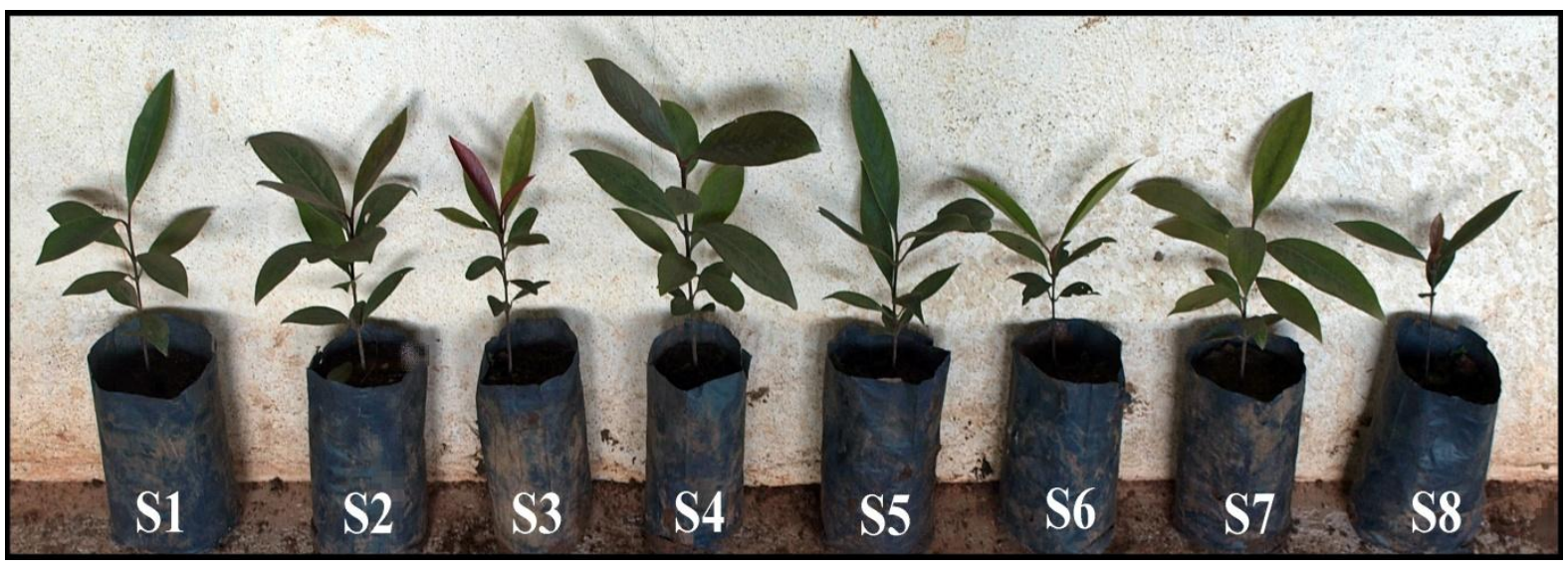

Plate 4: Influence of seed treatments on seedling growth in seed stored for 90 days

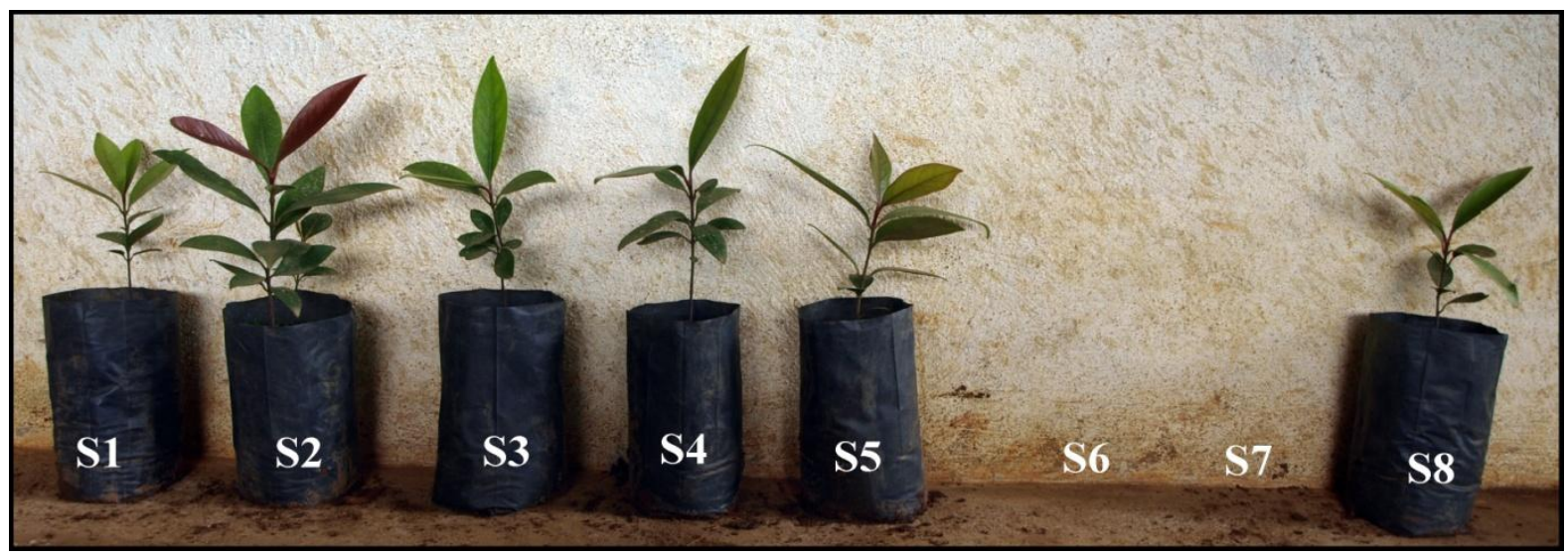




\section{Effect of seed treatment on seedling growth}

The effect of different seed treatment on growth of seedling showed significant variation for all the growth parameter. Seed treated with mechanical scarification of seed coat showed maximum collar diameter, average number of leaves, root weight, shoot weight while root length and shoot length were found maximum in seed treated with $\mathrm{GA}_{3}$. The minimum collar diameter and root length were observed in hot water treatment while other growth parameters were lowest in seed treated with hydrogen peroxide (Table 2).

The maximum collar diameter, average number of leaves, root length and shoot length were recorded in seed stored up to 60 days it could be due to the presence of favourable growth condition manifested by environment. Ologundudu et al., (2013) conducted study on effect of light on Delonix regia, Abelmoschus esculentus, Amaranthus cruentus, Celosia argentea and Corchorus olitorius. They revealed that the light condition affect development and germination of seedlings. The result is in line with Silveira et al., (2014) study concluded that seed storage for short periods does not reduce seedling growth and survival of Mimosa foliolosa.

Root weight and shoot weight were found maximum in seed stored up to 90 days it could be due to the to the enhanced root length, shoot length, collar diameter and number of leaves per plant. These parameters have led to increase overall photosynthesis rate within the plant and resulted in higher biomass production. Maximum values for collar diameter, average number of leaves, root weight and shoot weight were recorded in seed treated with mechanical scarification of seed coat it could be due to the mechanical damaging of seed coat; it was an efficient method for breaking seed coat dormancy. It improved seed imbibitions and germination (Botsheleng et al., 2014), so the water, oxygen and soil nutrient is available and the growth of seedling was fast. Root length and shoot length were found maximum in seed treated with $\mathrm{GA}_{3}$ could be due to the combine effect of scarification of seed coat and $\mathrm{GA}_{3}$. Mechanical Scarification of seed removes the impermeable seat coat and $\mathrm{GA}_{3}$ helps in intermodal and sub-apical elongation and root growth.

Gurung et al., (2014) studied the effect chemicals and growth regulators on germination, vigour and growth of passion fruit. They concluded that application of $\mathrm{GA}_{3}$ might have boosted growth by increasing cell multiplication and cell elongation resulting in better plant growth. The result is in line with Chandrashekara (1996) where the study has revealed that seedling vigour, seedling growth and dry matter were high in seed soaked in $\mathrm{GA}_{3}$ for 24 hours.

The study has concluded that seed storage and seed treatment had great impact on seedling growth. The overall results indicated that seed stored up to 60 days and treated with mechanical scarification of seed coat treatment best for the growth of seedling of Garcinia gummi-gutta.

\section{References}

Anonymous, 1996. The wealth of India. Published by Council of Scientific and Industrial Research, New Delhi, IX pp. 225-229.

Bhandari, A.K., 1998. Weight watchers delight Amruth. Punjab Horticulture Journal, 6(2): 27-28.

Botsheleng, B., Mathowa, T. and Mojeremane, W., 2014. Effects of pre-treatments methods on the germination of pod mahogany (Afzelia quanzensis) and mukusi (Baikiaeap lurijuga) seeds. International 
Journal of Innovative Research in Science Engineering and Technology, 3(1): 81088113.

Chandrashekara, R., 1996. Propagation studies of economically important tree species, M.Sc. Thesis submitted to UAS, Bangalore.

Gurung, N., Swamy, G.S.K. and Ubale, N.B., 2014. Effect of Chemicals and growth regulators on germination, vigour and growth of passion fruit (Passiflora edulis Sims.). The Bioscan, 9(1): 155-157.

Hegde, R.S., Suryaprakash, A., Choth, L. and Bawa, K.S., 1998. Extraction of non-timber forest products in the forests of Biligiri Rangana hills, India. 1: Contribution to rural income. Economic Botany, 50 (3): 243-251.

Jayaprakash, G.K. and Sakariah, K.K., 1998. Determination of organic acids in Garcinia cambogia (Desr.) by high performance liquid chromatography. Journal of Chromatography, 806: 337-339.

Jena, B.S., Jayaprakasha, G.K., Singh, R.P. and Sakariah, K.K., 2002. Chemistry and biochemistry of (-) Hydroxycitric Acid from Garcinia. Journal of Agricultural and Food Chemistry 50: 10-22.

Ologundudu, A.F., Adelusi, A.A. and Adekoya, K.P., 2013. Effect of light stress on germination and growth parameters of Corchorus olitorius, Celosi argentea, Amaranthus cruentus, Abelmoschus esculentus and Delonix regia. National Science Biology, 5(4): 468-475.

Ramesh, B.R., Pascal, J.P. and Nouguier, C., 1997. Atlas of Endemics of the Western Ghats (India): Distribution of Tree species in the Evergreen and semi-evergreen
Forests. Institute Francais, Pondicherry.

Ravikumar, K. and Ved, D.K., 2000. 100 red listed medicinal plants of conservation concern in southern India. FRLHT, Bangalore, 146-149.

Richards, A.J., 1990. Studies in garcnia, dioecious tropical forest trees: Agamospermy. Botaniica Journal, Linnean Socity, 103: 233-250.

Saldanha, 1984. Flora of Karnataka. 1: pp-205. Shringeshwara, A.N., Kirana, V.C., Rajanna, M.D., Hareesh, G.R. and Balakrishna, G., 2000. Studies on Garcinia gummi-gutta (L) Robson, A non-timber forest product of shringeri taluk, Chikamagalur district, Karnataka. My Forest, 36 (1): 61-64.

Silveira, F.A.O., Negreiros, D., Ranieri, B.D., Silva, C.A., Araujo, L.M. and Fernandes, G.W., 2014. Effect of seed storage on germination, seedling growth and survival of Mimosa foliolosa (Fabaceae): implications for seed banks and restoration ecology. Tropical Ecology, 55(3): 385-392.

Steentoft, M., 1988. Flowering Plants in West Africa. 1st Edn., Cambridge University Press, Cambridge, pp: 352.

Subhash, C.M.D., 1996. The Kokum tree. Resonance, 3(4): 12-15.

Vasudeva, R., Hombegowda, H.C., Umashankar, R. and Ganeshaiah, K.N., 2003. Strategies for domestication of NTFP yielding species: A case study from the Central Western Ghats. In: Uma Shankar, R., Hiremath, Ankila J., Joseph, Gladwin C., and Rai, Nitin D. (eds). Proceedings of Policies, Management, Utilization and Conservation of NTFP's, pp: 36-39.

\section{How to cite this article:}

Aditya Kumar Jayant, N.M. Poonacha, G.M. Devagiri, Vijay Kumar Yadav and Chauhan, P.S. 2018. Effect of Seed Storage and Seed Treatments on Seedling Growth of Garcinia gummi-gutta (L.) Roxb. in Ponnampet, Western Ghat. Int.J.Curr.Microbiol.App.Sci. 7(06): 3874-3880. doi: https://doi.org/10.20546/ijcmas.2018.706.456 